\title{
Children who attempted suicide with agricultural poisons
}

\author{
A Amarasinghe ${ }^{1}$, T A S Prabhath ${ }^{2}$ \\ Sri Lanka Journal of Child Health, 2001; 30: 103-4
}

(Key words: Child, suicide, agricultural poisons, Sri Lanka)

\section{Introduction}

Suicide is quite rare in children, but it's incidence increases with the arrival of puberty. Unfortunately, Sri Lanka does not have age specific suicide rates. In U.S.A., the age specific suicide rate in 5-14 years old children was 0.8 per 100,000 in 1986 .

We are reporting four children who were admitted to Base Hospital Hambantota during July to September 2001, having ingested agricultural poison with a desire to kill themselves.

\section{Case I}

An eleven year old boy from Mamadala, an agricultural village, $18 \mathrm{~km}$ from Hambantota was admitted with a history of self-ingestion of Seephos (Chloroprifos-Organophoshate).

He came from a poor agricultural family of three children. His father had died 7 years back and mother owned a small paddy field. His school attendance and school performances were normal.

The child had stolen money from his mother and brother three times. He stole ten rupees on the day of the incident, and he was admonished by his mother for this. She wanted to inform this to his teachers. The child was afraid of this and took poison. The attempt was impulsive and he had no features of a psychiatric disorder. He came from a supportive family. There were no suicidal ideas after the attempt.

He did not have any systemic signs and symptoms of poisoning on admission. Gastric lavage and observation were done. Mother and brother were advised regarding handling bad behaviour of the child and he was discharged after 3 days.

${ }^{1}$ Consultant Paediatrician, ${ }^{2}$ Medical Officer/Mental Health, Base Hospital, Hambantota.

\section{Case II}

An eleven year old girl from Gonagamuwa an agricultural village, $32 \mathrm{~km}$ from Hambantota, was admitted with a history of ingestion of Fentan (Organophosphate) with the intention of killing herself. She came from a semi-agricultural family, her father being a mason cum farmer. She was the third of a family of four children and her school performance was average. She had a quarrelsome personality, had few friends and said that she was bullied by peers.

She had quarrelled with her friends and refused to go to school saying that she was being bullied by her classmates. Mother had warned her saying that she will be punished by the father. The suicidal attempt was impulsive and she had no features of a psychiatric disorder. There were no previous suicidal attempts and she did not have any suicidal ideas after the attempt.

She was referred to Base Hospital Hambantota from District Hospital Tissamaharama. She was treated with basic management of poisoning. As she had respiratory and cardiac symptoms she was treated with atropine, IV fluids, O2, and nebulisations. As her symptoms were persisting she was transferred to the Intensive Care Unit of General Hospital Matara. After treatment she was discharged from hospital in three days. As she needed behavioural therapy she underwent behavioural management at the psychiatry clinic of Base Hospital Hambantota.

\section{Case III}

A ten year old boy from Koggalla, a poor agricultural village $20 \mathrm{Km}$ from Hambantota, was admitted with a history of self ingestion of Deltamethon (pyrethroid group). 
His father was a poor farmer and his mother had suicidal ideas at 14 years of age. He was the third in a family of four. His family was stable and school performance was average. He had frequent episodes of asthma and was on an inhaler for that. He was defaulting treatment for asthma and mother has advised him on that particular day to take medicine. He got angry over that and took poison. The attempt was impulsive and he had no features of a psychiatric disorder. He came from a supportive stable family.

As he did not have any signs and symptoms of systemic poisoning only gastric lavage and observation were done. As there were suicidal ideas, he is currently being followed up at the psychiatric clinic.

\section{Case IV}

A ten year old girl from Angunukolapelassa $30 \mathrm{Km}$ from Hambantota was admitted with a history of selfingestion of Chloroprifos (Organophosphate).

Her mother was employed in the Middle East for the last four years and lost contact with the family. Father who was a farmer used to blame the children under the influence of alcohol regarding their studies, even though their school performances were normal. She did not have any psychiatric illnesses and she was the third of a family of three children, who are being looked after by paternal relations Father had left home two days prior to the incident abandoning the children. She did not have any suicidal ideas after the attempt.

She had signs and symptoms of organophosphate poisoning. Standard management of organophosphate poisoning was done and child was discharged from the Base Hospital Hambantota after four days. Father was advised regarding parenting.

\section{Discussion}

In all four children, significant suicidal behaviour, which is defined as "any self destructive statement or action expressed with explicit desire to kill oneself and offered whether spontaneously or upon interview" were observed. All these children came from an agricultural community which is undergoing severe economic hardships due to the prevailing drought in Hambantota district.
In studies done in other countries most suicidal children were diagnosed as having depressive or conduct disorders. Other factors which contributed to suicidal behaviour were abused mother, abusive father, reports of suicidal behaviors by other family members and recent stressful life events.

None of these four children had psychiatric disorders but all of them have seen their adult relatives or friends taking agricultural poisons and dying. Availability of agricultural chemicals in households and stressful life events (sometimes trivial) led these children to attempt suicide.

In cases of attempted suicide it is extremely important to assess the incidents leading to the event and precipitating factors. After correct assessment by a doctor trained in psychiatry the child and the family should be followed up. Recent appointment of trained medical officers in psychiatry to base and district hospitals in Sri Lanka due to dearth of consultant psychiatrists have immensely helped to follow up such children.

\section{References}

1. Bark P. Basic child psychiatry - 6th edition, Blackwell science, 1995.

2. Carlson G. Suicidal behavior and psychopathology in children and adolescents, Current Opinion in Psychiatry, 1990 (b): 449552.

3. Fernando R. Management of poisoning. National Poisons Information Center, National Hospital of Sri Lanka. (1998) 
